\title{
PENGARUH KOMPETENSI AUDITOR INTERNAL TERHADAP KUALITAS AUDIT (KASUS PADA SPI PUSAT PT POS)
}

\author{
Vienanty Rahmawati Muslim
}

\begin{abstract}
ABSTRAK
Penelitian ini bertujuan untuk mengetahui seberapa besar pengaruh kompetensi mempengaruhi kualitas audit. Hipotesis dalam penelitian ini, yaitu kompetensi memiliki pengaruh positif terhadap kualitas audit. Metode yang digunakan dalam penelitian ini adalah metode deskriptif-verifikatif. Teknik yang digunakan dalam pengambilan sampel adalah teknik sampel jenuh atau sensus. Data dalam penelitian ini merupakan data primer yang diperoleh dari penyebaran kuesioner kepada auditor internal yang bekerja di SPI Pusat PT POS sebanyak 22 orang. Pengolahan data digunakan teknik Korelasi Pearson Product Moment untuk mengetahui hubungan dan arahnya, sedangkan Koefisien Determinasi (Kd) untuk mengetahui besarnya pengaruh dengan bantuan software IBM SPSS V 20 for windows. Dari hasil pengujian statistik menunjukkan hipotesis diterima, yaitu menyatakan bahwa kompetensi memiliki pengaruh positif terhadap kualitas audit dengan nilai koefisien korelasi 0,855 , yang berarti bahwa semakin tinggi kompetensi maka kualitas audit yang dihasilkan semakin tinggi, begitu pula sebaliknya. Nilai koefisien determinasi $73,1 \%$, artinya $73,1 \%$ kualitas audit dipengaruhi oleh kompetensi dan $26,9 \%$ ditentukan oleh faktor lain di luar model penelitian ini.
\end{abstract}

Kata kunci : Kompetensi, Kualitas Audit

\section{Pendahuluan}

BUMN dan BUMD merupakan perusahaan negara dan daerah yang melayani masyarakat. Dalam BUMN dan BUMD pun diperlukan juga pengawasan terhadap pengalokasian dana yang telah diberikan oleh pemerintah pusat dan daerah agar lebih transparan. Sama seperti sektor swasta maka manajemen perlu mendelegasikan tugas, tanggung jawab dan wewenangnya kepada pihak lain yaitu auditor internal yang berada di badan SPI (Satuan Pengawasan Intern). Dalam Tugiman (2000: 9), menyatakan bahwa:

Pembentukan audit internal di Indonesia, khususnya BUMN dan BUMD, diatur berdasarkan PP No. 3 tahun 1983 untuk Persero dan PP No. 13 tahun 1998 untuk Perum dan Peraturan Menteri Dalam Negeri No. 1 tahun 1984 untuk BUMD yang intinya sebagai berikut:

1. Satuan pengawasan intern bertugas membantu direktur utama dalam mengadakan penilaian atas sistem pengendalian, (manajemen), dan pelaksanaannya pada badan usaha yang bersangkutan dan memberikan saransaran perbaikan.

2. Pimpinan BUMN dan BUMD menggunakan pendapat dan saransaran dari satuan pengawasan intern sebagai bahan untuk melaksanakan penyempurnaan pengelolaan (manajemen) perusahaan yang baik dan dapat dipertanggungjawabkan.

Tanggung jawab atas pengelolaan BUMN dan BUMD bukan hanya terhadap pemerintah akan tetapi kepada masyarakat Indonesia pada umumnya. Keberadaan auditor internal di divisi SPI ini seharusnya dapat membantu manajemen dalam mempertanggung pengelolaannya dalam fungsi pengawasannya, sayangnya BUMN dan BUMD pun belum lepas dari beberapa kasus yang secara tidak langsung dapat merugikan negara. Padahal BUMN dan 
BUMD ini sangat penting untuk hajat hidup orang banyak, namun dengan adanya beberapa kasus dalam BUMN dan BUMD, membuat masyarakat mempertanyakan mengenai pengelolaan atas asset yang seharusnya dikelola sebaik mungkin.

Menurut data Badan Pemeriksa Keuangan (BPK) dalam Ikhtisar Hasil Pemeriksaan Semester (IHPS) II (2011: 256) atas SPI di 5 BUMN masih banyak kelemahannya. Sesuai dengan COSO (Committee of Sponsoring Organizations of the Treadway Commission) Framework pengendalian intern entitas direviu berdasarkan lima unsur, yaitu lingkungan pengendalian, penaksiran resiko, aktivitas pengendalian, informasi dan komunikasi serta pemantauan. Hasil pemeriksaannya yaitu:

1. Lingkungan

kelemahannya:

pengendalian,

a. Penerapan sistem manajemen sumber daya manusia berbasis kompetensi (MSDM-BK) yang memadai belum sepenuhnya dilaksanakan.

b. Perputaran pegawai pada kegiatan fungsi utama perusahaan, yaitu divisi operasional dan pemasaran cukup tinggi mengakibatkan perusahaan memiliki resiko kegagalan dalam mencapai kinerja.

c. Pelaksanaan tugas dan wewenang tiap-tiap direksi tidak didukung oleh pembagian tugas dan wewenang yang memadai.

2. Penaksiran resiko, kelemahannya:

a. Penerapan manajemen resiko belum sepenuhnya dilaksanakan.

b. Rencana jangka panjang perusahaan tidak disusun sehingga perusahaan tidak mempunyai dasar pengembalian keputusan.

c. Kegiatan penilaian resiko belum dilaksanakan secara memadai.

d. Belum terdapat Key Performance Indicators (KPI).

3. Aktivitas pengendalian, kelemahannya: a. Pengawasan terhadap tenaga kerja outsourching untuk kegiatan pelayanan pelanggan lemah.

b. Pengendalian atas rumah dinas atau rumah jabatan belum memadai.

c. Acuan kerja kegiatan pemasaran belum sepenuhnya dilaksanakan sesuai dengan ISO 9001.

4. Informasi dan komunikasi, kelemahannya:

a. Penyampaian informasi mengenai pelayanan pelanggan belum memadai.

b. Pengendalian teknologi informasi atas prosedur keadaan darurat belum ditetapkan.

c. Rencana strategis teknologi informasi dan kelengkapannya yang dapat dijadikan acuan dalam pengembangan sistem teknologi informasi belum tersedia.

d. Data pembayaran pelanggan melalui transfer bank belum diikuti updating data biling yang memadai.

5. Pemantauan, kelemahannya:

a. Satuan pengawasan intern belum melaksanakan fungsi dan tugasnya secara optimal sehingga penyelesaian temuan berlarut-larut.

b. Tugas dan fungsi komite audit perusahaan belum dilaksanakan secara optimal sesuai dengan GCG.

c. Tindak lanjut hasil pemeriksaan satuan pengawas intern belum berjalan efektif sehingga penyimpangan yang terjadi tidak dapat segera diperbaiki/diambil tindakan koreksi atau pemulihan.

d. Satuan pengawas intern perusahaan belum optimal melaksanakan fungsi dan tugas sebagai aparat pengawas internal sehingga tidak ada pemantauan yang memadai terhadap pelaksanaan kegiatan perusahaan yang memberi dampak atas kerugian yang terjadi.

Penyebab dari kasus-kasus kelemahan SPI di BUMN menurut Badan Pemeriksa Keuangan (BPK) dalam Ikhtisar Hasil Pemeriksaan Semester (IHPS) II 
(2011 : 259) adalah manajemen/direksi dan pelaksana belum sepenuhnya mematuhi ketentuan yang berlaku serta kurang cermat dalam melaksanakan tugas. Hal ini menunjukan bahwa fungsi pelaksanaan pengendalian dan pengawasan intern belum berjalan optimal karena tidak dipatuhinya aturan dan kecermatan dari para pelaksana pengawasan dan pengendalian intern. Auditor internal yang menjalani tugas utamanya yaitu pengawasan masih kesulitan dalam memberikan pemecahan atas temuan audit sehingga pernyimpangan yang terjadi tidak dapat cepat terpecahkan. Dengan banyaknya kasus di atas maka kualitas audit pun tidak akan tercapai karena tidak adanya dorongan dari manajemen/direksi terhadap komite audit yang efektif, hal itu ditunjukan dengan tidak dipenuhinya ketentuan yang berlaku dan pencapaian GCG pun sulit dilakukan.

PT POS merupakan salah satu BUMN yang bergerak di bidang komunikasi dan seiring perkembangan dunia usaha kini PT POS mulai melakukan pengembangan usaha bukan hanya di bidang komunikasi saja tapi salah satunya di bidang perbankan. Seiring dengan semakin kompleksnya usaha yang dijalani PT POS maka PT POS pun memerlukan pengawasan dan pengendalian pada manajemennya dengan dibentuknya SPI yang telah ditentukan oleh perundangundangan. Dalam pelaksanaan auditnya, PT POS pun mempunyai permasalahan dimana kualitas auditnya masih kurang karena kompetensi auditor internnya masih kurang pula sehingga auditor internal kesulitan menemukan penyimpangan yang ada. Pemecahan atas penyimpangan yang terjadi pun tidak dapat dilakukan dengan segera. Hal ini didasarkan pada hasil wawancara penulis dengan manajer sekretariat SPI dan salah satu auditor internal di PT POS.

Selain itu, berdasarkan simpulan pemeriksaan BPK dalam IHPS semester 1 mengenai kesesuaian dengan ketentuan terhadap SPI PT POS (Lampiran 30, 2011 :
65), hasilnya adalah tidak sesuai. Hal ini menunjukan bahwa SPI PT POS dalam melaksanakan pengendaliannya belum sesuai dengan ketentuan yang telah ditetapkan begitu juga dengan pelaksanaan audit intern yang dilakukan para auditor internalnya. Bila hal ini tidak segera diperbaiki maka akan berdampak pada kegagalan pelaksanaan pengawasan dan pengendalian intern dan lebih jauhnya pencapaian tujuan perusahaan tidak akan dapat tercapai karena bila terjadi penyimpangan akan sulit untuk diatasi.

\section{Landasan Teori}

Definisi kualitas audit menurut De Angelo (Rosnidah, 2011 : 458) menyatakan bahwa, "kualitas audit sebagai kemungkinan auditor dapat mendeteksi dan melaporkan kesalahan atau kecurangan dalam sistem informasi akuntansi klien.' Kemungkinan auditor mendeteksi kecurangan berhubungan dengan kompetensi auditor internal, sedangkan kemungkinan auditor melaporkan kecurangan berhubungan dengan indenpendensi auditor. Bila dilihat mengenai kualitas audit dan banyaknya kasus kelemahan SPI di BUMN, maka dapat dikatakan bahwa kualitas audit di BUMN masih kurang karena dalam pelaksanaan auditnya, auditor internal belum mampu menjalankan fungsi dan tugasnya sehingga penyelesaian temuan berlarut-larut dan penyimpangan yang terjadi tidak dapat segera diperbaiki.

Kualitas audit dalam penelitian ini difokuskan pada pelaksanaan auditnya. Pelaksanaan audit merupakan suatu aktivitas yang penting dalam proses pengawasan dan pengendalian yang dilakukan oleh auditor internal. Dalam pelaksanaan audit seorang auditor dapat menilai sejauh mana kinerja manajemen dan dapat mengetahui berbagai temuantemuan di lapangan. Jika pelaksanaan auditnya berkualitas seorang auditor akan cepat mengetahui temuan-temuan yang mengandung resiko bagi perusahaan dan dengan segera melakukan tindakan 
preventif dan korektif atas temuan itu dengan reviu-reviu yang diberikan. Kualitas audit ini harus dibangun dari awal pelaksanaan audit hingga pemberian rekomendasi. Hal tersebut serupa dengan pernyataan Ahmad et al (2011 : 65) yang menyatakan bahwa, "kualitas audit harus dibangun sejak awal pelaksanaan audit hingga pelaporan dan pemberian rekomendasi."

Ruang lingkup pelaksanaan audit internal seluas fungsi manajemen, sehingga cakupan tugasnya meliputi, mulai dari pengamanan asset, investigasi kecurangan, evaluasi pengawasan, ketaatan pada peraturan dan banyak lagi. Hal ini sesuai dengan yang diungkapkan Staciokas dan Rupsys (Al Matarneh, 2011 : 101) bahwa:

Nowadays internal audit covers many areas. Internal audit functions are delegated to the internal audit department. Internal audit department is usually responsible for:

- Assessing of asset safeguards;

- Fraud investigations;

- Evaluation of internal controls;

- Operating process review and assessment;

- Review of accounting and financial information;

- Compliance (of procedures, policies, legal acts, etc.) audits;

- Assessment of efficient usage of recourses.

Luasnya cakupan pekerjaan audit ini harus diiringi dengan sumber daya manusia yang kompeten. Dengan sumber daya manusia yang kompeten pelaksanaan audit diharapkan dapat memberi nilai tambah bagi perusahaan. Dalam menentukan kualifikasi auditor diperlukan standar yang ketat yang dilihat dari berbagai hal seperti pengalaman, pendidikan dan sertifikasi. Jika seorang auditor internal latar belakang pendidikannya bukan merupakan lulusan jurusan akuntansi dan tidak berpengalaman akan sulit bagi pelaksanaan audit nantinya serta kualitas audit yang dihasilkan tidak akan optimal.
Faktor-faktor penentu kualitas audit diantaranya adalah kompetensi dan independensi auditor internal. Hal ini didapat dari pernyataan AAA (American Accounting Association) Financial Accounting Standard Commitee (Christiawan, 2002 : 83) yang mengungkapkan bahwa, 'kualitas audit ditentukan oleh dua hal yaitu kompetensi dan independensi'. Hal ini diperkuat dengan hasil penelitian Hajiha dan Rafiee (2011: 390) yang mengungkapkan bahwa, ".....Internal Audit Function (IAF) quality is measured reports took more time if there were ambiguous items in by three criteria of objectivity, competence and internal annual reporting and extraordinary items in income audit size (IAS)....". Menurut pernyataan AICPA (Al Matarneh, 2011 : 102) yang menyatakan bahwa:

Factors of quality internal audit function to include: (1) Competence which is measured by educational level, and Professional certificates, (2) objectivity which is measured by the parties that addressed the internal audit report to them, and the parties who responsible for the appointment of internal auditors,(3) quality of performance of tasks, which measured by the accuracy and adequacy of audit programs, and the scope of audit.

Berdasarkan pernyataan dan penelitian di atas, maka salah satu hal yang menentukan kualitas audit adalah kompetensi auditor internal. Kompetensi didapatkan bukan tiba-tiba melainkan dari hasil pendidikan, pengalaman dan sertifikasi. Seorang auditor yang kompeten dapat memberikan reviu dan menjadi konsultan bagi manajemen, tidak hanya itu auditor juga dapat memberi nilai tambah bagi perusahaan. Oleh karena itu, untuk menunjang kompetensinya seorang auditor membutuhkan pendidikan yang berkelanjutan.

Kompetensi merupakan hal penting yang harus dimiliki auditor internal karena itu merupakan tanggung jawab dari auditor internal dalam menjalankan tugasnya 
seperti yang diungkapkan oleh Tugiman (Astuti, $2010: 3$ ) yang menyatakan bahwa, 'kompetensi adalah kemampuan profesional merupakan tanggung jawab dari bagian audit internal dan masing-masing pemeriksa internal.' Kompetensi juga dapat menentukan keberhasilan dalam pelaksanaan audit, tanpa kompetensi pelaksanaan audit menjadi kurang berkualitas.

Auditor yang tidak kompeten tidak akan bisa membantu manajemen dalam memecahkan masalah-masalah yang mengandung resiko, padahal tugas auditor di era ini lebih difokuskan kepada pengawasan dan pengendalian terhadap area-area yang mengandung resiko bukan hanya audit atas kepatuhan saja. Kompetensi yang rendah juga akan mengakibatkan kegagalan dalam audit karena auditor akan kesulitan dalam menemukan temuan-temuan yang berkenaan dengan terjadinya penyimpangan. Sejalan dengan hal tersebut menurut Perry (Mansouri et al, 2009 : 19) menyatakan bahwa, 'The five most common reasons for audit failures which they are as follows: scope restrictions; incompetence; auditing by conversation; not critically evaluating transactions; and lack of objectivity and skepticism'. Jadi dapat disimpulkan bahwa kompetensi auditor mempunyai peran yang penting dalam pelaksanaan dan kualitas audit.

\section{Metode Penelitian}

Penelitian ini merupakan penelitian deskriptif-verifikatif, dimana tujuannya untuk menyajikan gambaran secara terstruktur, faktual dan akurat, selanjutnya untuk meneliti hubungan antar variabel akan dianalisis statistik untuk diambil suatu kesimpulan. Penelitian deskriptif adalah penelitian yang bertujuan untuk memperoleh gambaran ciri-ciri variabel, sedangkan penelitian verifikatif adalah suatu penelitian yang bertujuan untuk menguji kebenaran suatu hipotesis yang telah dibuat melalui pengumpulan data dilapangan.

Mengingat jenis atau bentuk penelitian adalah deskriptif-verifikatif yang dilaksanakan melalui pengumpulan data di lapangan, maka metode penelitian yang dilaksanakan adalah metode survey. Metode survey yaitu pengumpulan data yang dilakukan terhadap suatu unit analisis untuk mendapatkan keterangan-keterangan yang jelas terhadap suatu masalah dengan menggunakan kuesioner sebagai alat pengumpulan data pokok.

Populasi penelitian adalah Divisi Satuan Pengawas Intern (SPI) pusat yang berstatus sebagai auditor internal di PT POS Indonesia sebanyak 22 orang. Metode yang digunakan dalam penarikan sampel ini adalah sampling jenuh atau sensus, sehingga jumlah sampel sama dengan jumlah populasi.

\section{Teknik Analisis Data}

\section{a. Analisis Deskriptif}

Berdasarkan hasil jawaban kuesioner yang disampaikan kepada seluruh responden, berikut ini akan dijelaskan secara rinci mengenai kompetensi auditor internal dan kualitas audit. Untuk menentukan kriteria pengklasifikasian untuk variabel $X$ dan $Y$ yang mengacu pada ketentuan yang dikemukakan oleh Umar (1999 : 171), dimana rentang skor dicari dengan rumus sebagai berikut:

$$
R_{s}=\frac{n(m-1)}{m}
$$

Keterangan:

$$
\begin{array}{ll}
\mathrm{R}_{\mathrm{s}} & =\text { Rentang Skor } \\
\mathrm{m} & =\text { Jumlah alternatif jawaban tiap item } \\
\mathrm{n} & =\text { Jumlah sampel }
\end{array}
$$

Menentukan skor ideal untuk variabel $X$ dan $Y$ karena jumlah itemnya sama maka skor idealnya tidak per variabelnya. Skor tertinggi (banyaknya 
responden dikali skor tertinggi) yaitu $5 \times 22$. Skor terendah (banyaknya responden dikali skor terendah) yaitu $1 \times 22$. Lalu dihitung rentang skornya yaitu:

$$
\mathrm{R}_{\mathrm{s}}=\frac{22 \times 4}{5}
$$

$=17,6$ dibulatkan menjadi 18

Dari perhitungan di atas didapat interval skor untuk pengolahan data yang digunakan memiliki rentang sebesar 18 setiap kelasnya. Merujuk perhitungan di atas angka kriteria penilaian dimulai dari 22 karena sesuai dengan instrumen yang digunakan dalam penelitian ini sedangkan nilai tertinggi sebesar 110 . Berikut ini kriteria penilaian yang digunakan:

\section{Tabel 1}

\section{Kriteria Rentang Pengklasifikasian}

\begin{tabular}{|c|c|}
\hline Skor & Kategori \\
\hline $22-39$ & $\begin{array}{c}\text { Sangat } \\
\text { Rendah }\end{array}$ \\
\hline $40-57$ & Rendah \\
\hline $58-75$ & Sedang \\
\hline $76-93$ & Tinggi \\
\hline $94-110$ & $\begin{array}{c}\text { Sangat } \\
\text { Tinggi }\end{array}$ \\
\hline
\end{tabular}

\section{b. Pengujian Hipotesis}

Pengujian hipotesis dalam penelitian ini menggunakan pengujian korelasi. Data yang digunakan dalam penelitian ini adalah interval, linier dan berdistribusi normal sehingga teknik korelasi yang digunakan adalah Korelasi Peason Product Moment. Hipotesis dari penelitian ini adalah sebagai berikut

"Kompetensi auditor internal berpengaruh positif terhadap kualitas audit."

Rumusan korelasi product moment yang digunakan, yaitu:

$$
r_{x y=} \frac{N \sum X Y-\left(\sum X\right)\left(\sum Y\right)}{\sqrt{\left\{N \sum X^{2}-\left(\sum X\right)^{2}\right\}\left\{N \sum Y^{2}-\left(\sum Y\right)^{2}\right\}}}
$$

(2007 : 212)

Sumber: Sugiyono

Koefisien korelasi ( $r$ ) menunjukan derajat korelasi antara $\mathrm{X}$ dan $\mathrm{Y}$. Nilai koefisien korelasi harus terdapat dalam batas-batas: $-1<r<+1$. Tanda positif menunjukan adanya hubungan positif/korelasi langsung antara kedua variabel yang berarti. Setiap kenaikan nilainilai $X$ akan diikuti kenaikan nilai-nilai $Y$, begitu pula sebaliknya. Pedoman menilai korelasi menurut Umar (2008: 14) yaitu sebagai berikut:

1. Jika nilai $r$ menuju +1 menunjukkan korelasi menuju kuat dan positif, artinya jika variabel $X$ bertambah, bertambah pula nilai variabel $Y$. Jika variabel $X$ berkurang, berkurang pula nilai variabel Y.

2. Jika nilai $r$ menuju -1 menunjukkan korelasi menuju kuat dan negatif, artinya jika variabel $X$ bertambah, nilai variabel $Y$ berkurang. Jika variabel $X$ berkurang, nilai variabel $Y$ bertambah.

3. Jika nilai $r$ menuju 0 menunjukkan korelasi menuju lemah (tidak ada hubungan), artinya jika variabel $X$ bertambah atau berkurang, nilai variabel $Y$ tidak mengikutinya. Jika variabel $Y$ bertambah atau berkurang, nilai variabel $X$ tidak mengikutinya.

Selanjutnya analisa korelasi dapat dilanjutkan dengan menghitung koefisien determinasi. Tujuan dari perhitungan koefisien determinasi yaitu untuk mengetahui pengaruh variabel $X$ terhadap variabel $Y$. Nilai koefisien determinasi berada antara 0 sampai $1(0 \leq K D \leq 1)$ dengan ketentuan:

a. Jika nilai Koefisien Determinasi $(K D)=$ 0 , berarti tidak ada pengaruh variabel independen terhadap variabel dependen.

b. Jika nilai Koefisien Determinasi $(K D)=$ 1, berarti variansi (naik/turunnya) variabel dependen adalah 100\% dipengaruhi oleh variabel independen. 
c. Jika nilai Koefisien Determinasi (KD) berada diantara 0 dan 1 , berarti besarnya pengaruh variabel independen terhadap variasi variabel independen adalah sesuai dengan nilai $\mathrm{KD}$ itu sendiri, dan selebihnya dipengaruhi oleh faktor-faktor lain.

Dimana hal ini dapat dirumuskan dengan cara mengkuadratkan koefisien korelasi yang ditemukan . Jadi:

$$
\text { koefisien determinasi }=r_{x y}{ }^{2} \mathrm{x}
$$

\section{Hasil Dan Pembahasan}

Secara umum, gambaran mengenai variabel $\mathrm{X}$ (kompetensi) secara keseluruhan dapat dilihat pada tabel rekapitulasi ratarata jawaban untuk variabel $X$ (kompetensi) di bawah ini:

\section{Tabel 2}

\section{Rekapitulasi Rata-Rata Jawaban untuk Variabel X (Kompetensi)}

\begin{tabular}{|c|c|c|c|}
\hline No. & Indikator & $\begin{array}{l}\text { Rata- } \\
\text { Rata }\end{array}$ & Kategori \\
\hline 1 & Penyusunan Staf & 82,5 & Tinggi \\
\hline 2 & $\begin{array}{l}\text { Pengetahuan, } \\
\text { Keterampilan dan } \\
\text { Disiplin }\end{array}$ & 89,3 & Tinggi \\
\hline 3 & Supervisi & 90 & Tinggi \\
\hline 4 & $\begin{array}{l}\text { Hubungan dan } \\
\text { Komunikasi Antar } \\
\text { Karyawan }\end{array}$ & 90,7 & Tinggi \\
\hline 5 & $\begin{array}{l}\text { Pendidikan } \\
\text { Berkelanjutan }\end{array}$ & 93 & Tinggi \\
\hline 6 & $\begin{array}{l}\text { Keahlian } \\
\text { Profesional }\end{array}$ & 77 & Tinggi \\
\hline & Total & 522,5 & \\
\hline & Rata-Rata & 87,1 & Tinggi \\
\hline
\end{tabular}

Sumber: Hasil penelitian yang telah diolah

Berdasarkan perhitungan pada tabel 2, dari keenam indikator tersebut menghasilkan nilai total skor rata-rata sebesar 522,5. Kemudian dari total skor rat-rata dari setiap indikator, diperoleh ratarata sebesar 87,1 dan termasuk dalam

kategori tinggi. Kompetensi auditor internal di PT POS tinggi didasarkan pada pencapaian pada indikator kompetensinya dimana para auditor internal di PT POS semuanya memenuhi kualifikasi pendidikan untuk menjadi seorang auditor internal, mereka juga memiliki pengetahuan, keterampilan dan menguasai beberapa disiplin ilmu untuk menunjang pelaksanaan tugasnya. Selain itu juga, para auditor internal ini selalu dipantau tugasnya oleh pemimpinnya sehingga pelaksanaan tugasnya akan semakin baik, hubungan dan komunikasi antar sesama auditor internal terjalin dengan sangat baik serta penyampaian laporan dan reviu kepada auditee dapat disampaikan dengan jelas dan dapat dipahami auditee. Para auditor intenal di PT POS pun senantiasa mengikuti pendidikan berkelanjutan untuk menunjang keahlian profesionalnya.

Secara umum, gambaran mengenai variabel $Y$ (kualitas audit) secara keseluruhan dapat dilihat pada tabel rekapitulasi rata-rata jawaban untuk variabel Y (kualitas audit) di bawah ini:

\section{Tabel 3}

\section{Rekapitulasi Rata-Rata Jawaban untuk Variabel Y (Kualitas Audit)}

\begin{tabular}{|c|c|c|c|}
\hline No. & Indikator & $\begin{array}{l}\text { Rata- } \\
\text { Rata }\end{array}$ & Kategori \\
\hline 1 & $\begin{array}{l}\text { Perencanaan } \\
\text { Pemeriksaan }\end{array}$ & 87,8 & Tinggi \\
\hline 2 & $\begin{array}{l}\text { Pengujian dan } \\
\text { Pengevaluasian } \\
\text { Informasi }\end{array}$ & 91,3 & Tinggi \\
\hline 3 & $\begin{array}{l}\text { Penyampaian } \\
\text { Hasil } \\
\text { Pemeriksaan }\end{array}$ & 89 & Tinggi \\
\hline 4 & $\begin{array}{l}\text { Tindak Lanjut } \\
\text { Hasil } \\
\text { Pemeriksaan }\end{array}$ & 87 & Tinggi \\
\hline & Total & 355,1 & \\
\hline & Rata-Rata & 88,8 & Tinggi \\
\hline
\end{tabular}


Berdasarkan perhitungan pada tabel 3 , diperoleh nilai total skor rata-rata sebesar 355,1 . Kemudian dari total skor rata-rata dari setiap indikator, diperoleh rata-rata sebesar 88,8 dan termasuk dalam kategori tinggi. Kualitas audit yang diukur dari pelaksanaan audit di PT POS dikatakan tinggi karena dalam indikator pelaksanaan auditnya telah tercapai semua dimana sebelum melakukan pemeriksanaan telah disusun rencana-rencana pemeriksaan sehingga pelaksaannya lebih terarah, pengujian dan pengevaluasian informasi pun dilakukan dengan seakurat mungkin agar informasi yang dihasilkan bukan merupakan informasi yang bias, dalam penyampaian hasil pemeriksaan pun semua dilaporkan dengan terperinci dan jelas sehingga diketahui keberhasilan atau kekurangan dari manajemen selama ini dan selalu diadakan reviu atau tindak lanjut hasil pemeriksaan atas rekomendasi yang diberikan kepada manajemen apakah telah dilakanakan atau belum.

Untuk mengetahui hubungan dan pengaruh kompetensi terhadap kualitas audit pada SPI Pusat PT POS, maka dilakukan perhitungan statistik dengan menggunakan analisis Korelasi Pearson Product Moment. Dari hasil perhitungan variabel kompetensi terhadap kualitas audit diperoleh hasil sebesar 0,855, hal ini menunjukkan bahwa kompetensi memiliki hubungan kuat dan pengaruh positif terhadap kualitas audit. Dimana jika kompetensi auditor tinggi maka kualitas audit pun tinggi, begitu pun sebaliknya.

\section{Kemudian untuk mengetahui seberapa besar pengaruh kompetensi terhadap kualitas audit, dapat diketahui dari besarnya koefien determinasi. Dari hasil perhitungan yang dilakukan diperoleh nilai koefisien determinasi sebesar 73,1\%. Hal ini menunjukkan bahwa besarnya pengaruh kompetensi terhadap kualitas audit sebesar $73,1 \%$ sedangkan $26,90 \%$ dipengaruhi oleh faktor-faktor lain.}

Dari hasil penelitian di atas dapat
disimpulkan bahwa kompetensi
berpengaruh positif terhadap kualitas audit

yang dihasilkan. Dimana peningkatan kualitas audit sangat bergantung pada tingkat kompetensinya. Jika auditor memiliki kompetensi yang baik maka auditor akan dengan mudah melakukan tugas-tugas auditnya sehingga kualitas audit yang dihasilkan baik pula. Sebaliknya jika kompetensinya kurang, maka dalam melaksanakan tugasnya auditor akan mendapatkan kesulitan-kesulitan sehingga kualitas audit yang dihasilkan akan kurang pula. Hasil penelitian ini serupa dengan penelitian-penelitian sebelumnya, seperti hasil penelitian Ahmad et al. (2011 : 71) mengungkapkan bahwa:

Untuk meningkatkan kualitas audit, seorang auditor sangat bergantung pada tingkat kompetensinya. Jika auditor memiliki kompetensi yang baik maka auditor akan dengan mudah melakukan tugas-tugas auditnya, dan sebaliknya jika rendah, maka dalam melaksanakan tugasnya auditor akan mendapatkan kesulitan-kesulitan sehingga kualitas audit yang dihasilkan akan rendah pula.

Menurut Al Matarneh (2011 : 107) mengungkapkan bahwa, "The results of the questionnaire indicate that internal auditors in Jordanian banks consider the competence, objectivity and performance of internal auditors as important factors affecting the internal audit quality".

Berdasarkan hasil penelitian di atas dapat disimpulkan bahwa kompetensi berpengaruh positif terhadap kualitas audit. Pengaruh kompetensi terhadap kualitas audit pun tinggi yaitu sebesar $73,1 \%$ sedangkan faktor lain selain kompetensi hanya berpengaruh $26,90 \%$. Oleh karena itu, setiap auditor internal bertanggung jawab untuk terus menjaga kualitas auditnya dengan meningkatkan kompetensinya melalui berbagai kegiatan seperti keikutsertaan dalam pendidikan berkelanjutan, seminar, simporsium dan sebagainya. Tanpa kompetensi yang baik pelaksanaan audit akan gagal, sebagaimana yang diungkapkan oleh Perry (Mansouri et al, 2009 : 19) menyatakan 
bahwa, 'The five most common reasons for audit failures which they are as follows: scope restrictions; incompetence; auditing by conversation; not critically evaluating transactions; and lack of objectivity and skepticism'.

\section{Kesimpulan dan Saran}

\section{Kesimpulan}

Penelitian ini bertujuan untuk mengetahui kompetensi, kualitas audit dan pengaruh kompetensi auditor internal terhadap kualitas audit di SPI Pusat PT POS. Berdasarkan hasil penelitian, dapat diambil kesimpulan sebagai berikut:

1. Berdasarkan hasil pengolahan data mengenai kompetensi auditor internal di PT POS termasuk dalam kategori tinggi, yang bermakna bahwa kompetensi auditor internal di PT POS telah memenuhi standar yang telah ditetapkan IIA.

2. Berdasarkan hasil pengolahan data mengenai kualitas audit di PT POS termasuk dalam kategori tinggi, yang bermakna kualitas audit yang diukur dari pelaksanaan audit di PT POS sudah sesuai dengan standar pelaksanaan yang ditetapkan SPAI.

3. Kompetensi auditor internal berpengaruh positif terhadap kualitas audit di SPI Pusat PT POS yang bermakna jika kompetensi bertambah maka kualitas audit pun bertambah, begitu juga sebaliknya.

\section{Saran}

Berdasarkan hasil penelitian yang telah dilakukan maka diajukan saran, antara lain:

1. Bagi Perusahaan

Untuk mempertahankan kualitas audit yang sudah tinggi maka kompetensi auditor internal harus selalu ditingkatkan dengan tetap mengikuti pelatihanpelatihan, simporsium, pendidikan berkelanjutan dan sebagainya yang dapat meningkatkan kompetensi.
2. Bagi Peneliti Lain

Untuk peneliti selanjutnya, diharapkan dapat meneliti kembali faktor-faktor lain yang dapat mempengaruhi kualitas audit. Selain itu, agar data yang diperoleh lebih akurat dan tidak bias yang menjadi responden dalam penelitian sebaiknya adalah auditee (pihak yang diperiksa).

\section{Daftar Pustaka}

Ahmad, Afridian Wirahadi. et al. (2011). "Pengaruh Kompetensi dan Independensi Pemeriksa terhadap Kualitas Hasil Pemeriksaan dalam Pengawasan Keuangan Daerah: Studi pada Inspektorat Kabupaten Pasaman". Jurnal Akuntansi dan Manajemen. 6, (2), 63-73.

Alim, M. Nizarul., Hapsari, Trisni dan Purwanti, Liliek. (2007). "Pengaruh Kompetensi dan Independensi terhadap Kualitas Audit dengan Etika Auditor sebagai Variabel Moderasi". Simporsium Akuntansi Ke X.1-26.

Al Matarneh, Ghassan. F.(2011). "Factors Determining the Internal Audit Quality in Banks: Empirical Evidence from Jordan". International Research Journal of Finance and Economics. Issue 73, 99-108.

Arens, Alvin A, Randal J, dan Beasley, Mark S. (2008). Auditing dan Jasa Assurance (Pendekatan Terintegrasi) Jilid I. Jakarta : Erlangga.

Arikunto, S. (2006). Prosedur Penelitian Suatu Pendekatan Praktek. Jakarta : PT Rineka Cipta.

Astuti, Wati Aris. (2010). "Pengaruh Independensi dan Kompetensi Auditor Internal terhadap Kualitas Pelaksanaan Audit Internal pada BUMN di Bandung". Jurnal Ekono Insentif Kopwil. 4, (2), 1-10.

Badan Pemeriksa Keuangan Republik Indonesia. (2011). Ikhtisar Hasil 
Pemeriksaan Semester I Tahun 2011. Jakarta.

. (2011). Ikhtisar Hasil Pemeriksaan Semester II Tahun 2011. Jakarta.

Christiawan, Y.J. (2002). "Kompetensi dan Independensi Akuntan Publik: Refleksi Hasil Penelitian Empiris". Jurnal Akuntansi dan Keuangan. 4, (2), 79-92.

Guy, Dan M., Alderman, C. Wayne dan Winters, Alan J. (2002). Auditing: Jilid 1. Jakarta: Erlangga.

(2003). Auditing: Jilid 2. Jakarta: Erlangga.

Hajiha, Zohreh and Rafiee, Azadeh. (2011). "The Impact of Internal Audit Function Quality on Audit Delays". Middle-East Journal of Scientific Research. 10, (3), 389-397.

Iskandar. (2009). Metodologi Penelitian Pendidikan dan Sosial (Kuantitatif dan Kualitatif). Jakarta : GP Press.

Lisda, R. (2007). "Pengaruh Kompetensi dan Objektivitas Fungsi Auditor Internal terhadap Pelaksanaan Pengendalian Intern (Survei pada Hotel Bintang Empat dan Lima Kota Bandung)". Jurnal Trikonomika Fakultas Ekonomi UNPAS. 7, (1), 86-96.

Mansouri, Ali., Pirayesh, Reza and Salehi, Mahdi (2009). "Audit Competence and Audit Quality: Case in Emerging Economy". International Journal of Business and Management. 4, (2), 17-25.

Marvira. (2010). Pengaruh Kompetensi dan Independensi Auditor Internal terhadap Kualitas Audit (Studi Kasus pada Unit Internal Auditor PT Telekomunikasi Indonesia, Tbk). Skripsi Fakultas Ekonomi Universitas Pajajaran Bandung : tidak diterbitkan.
Mulyadi. (2002). Auditing (Edisi 6). Jakarta : Salemba Empat.

Priyatno, Duwi. (2012). Cara Kilat Belajar Analisis Data dengan SPSS 20. Yogyakarta : Andi.

Rosnidah, Ida. (2009). "Kualitas Audit : Refleksi Hasil Penelitian Empiris." Jurnal Akuntansi. 13, (3), 1-16.

Rosnidah, Ida., Rawi dan Kamarudin. (2011). "Analisis Dampak Motivasi dan Profesionalisme terhadap Kualitas Audit Aparat Inspektorat Dalam Pengawasan Keuangan Daerah (Studi Empiris pada Pemerintah Kabupaten Cirebon)." Pekbis Jurnal. 3, (2), 456-466.

Said. (2009). Pengaruh Kompetensi, Independensi dan Skeptisme Profesional Auditor Internal terhadap Kualitas Pelaksanaan Audit Internal Instansi Pemerintah (Studi pada Instansi Pemerintah Pusat, 22 Lembaga Pemerintah Non Departemen). Tesis Fakultas Ekonomi Universitas Pajajaran Bandung : tidak diterbitkan.

Sawyer, Lawrence B. et al. (2005). Internal Auditing. Jakarta : Salemba Empat.

Silalahi, Dr.Ulber, MA. (2010). Metode Penelitian Sosial. Bandung : PT Refika Aditama.

Sugiyono. (2007). Metode Penelitian Administrasi. Bandung : CV Alfabeta.

Suraida, Ida. (2005). "Pengaruh Etika, Kompetensi, Pengalaman Audit dan Risiko Audit terhadap Skeptisisme Profesional Auditor dan Ketepatan Pemberian Opini Akuntan Publik". Sosiohumaniora. 7, (3), 186-202.

Tugiman, Hiro. (1997). Standar Profesional Audit Internal. Yogyakarta : Kanisius.

(2000). Pengantar Audit

Internal. Bandung: STT Telkom.

Umar, Drs. Husein, S.E.,M.M.,MBA. (1999). Metode Penelitian Aplikasi dalam Pemasaran. Jakarta : PT Gramedia Pustaka Utama. 
(2008). Desain Penelitian Akuntansi Keperilakuan. Jakarta: PT Raja Grafindo Persada
Wiratha, I.M. (2005). Pedoman Penulisan Usulan Penelitian, Skripsi dan Tesis. Yogyakarta: ANDI. 